\title{
NEUROVĚDY A RENESANČNÍ TEORIE UMĚNÍ
}

\author{
LIUBOV MARSOVA \\ Ústav pro dějiny umění, Filozofická fakulta Univerzity Karlovy \\ E-mail:marsovaliubov@gmail.com
}

\begin{abstract}
Neuroscience and Renaissance art theories

The article is about interactions between two disciplines: the history of art and neurology. Scientific researches in the field of neurology discover new perspectives in the humanitarian disciplines, including the art history. The article draws attention to two current themes: to the research of human empathy and mechanisms of bottom-up and topdown processing in visual perception. Those two parts the author of the article connects with the theory of art in Italy in the era of Renaissance. An unexpected comparison of discoveries in the field of neurology with the theory of the 16th century demonstrates, how useful can be the cooperation of the two disciplines. In the end of the article are proposed questions and tasks, with which the art history can deal in the light of scientific discoveries.
\end{abstract}

Keywords: bottom-up processing; top-down-processing; visual perception; Renaissance; neurology

\section{Úvod}

Velká část metod v uměnovědě byla založena na teorii opakování, na tezi, že ty nebo jiné konstrukce se v dějinách opakujív té či oné podobě. Tato vize se objevuje jak u představitelů „staré generace "Vídeňské školy v rámci formální analýzy, tak i ve 20. století $\mathrm{v}$ různých „odvětvích“ dějin umění: s podobnými nadčasovými koncepty pracují strukturalismus, vizuální teorie, feministické př́stupy či psychoanalýza.

Takové přístupy do jisté míry usnadňují uchopení historického materiálu, dávají jakýsi „klíčc" „nástroj“ pro teoretická uvažování. Značným př́nosem pro dějiny umění se může také stát spolupráce s jinými disciplínami, jejichž nejnovější poznatky mohou být aplikovány nejenom při zkoumání moderního a současného umění, ale i pro bádání věnovaná umění starému.

Inspirace, kterou dějinám umění přináší neurověda, byla postřehnuta Davidem Freedbergem a Vittoriem Gallesem. ${ }^{1}$ Problémům a možnostem vztahujícím se ke spolupráci dějin umění s neurovědou, kognitivní vědou apod. byla věnována pozornost i v českém prostředí v článku Ladislava Kesnera. ${ }^{2}$

Dějiny umění se díky těmto inspiracím konečně mohou vrátit $\mathrm{k}$ otázce emotivního prožitku uměleckého díla, který byl a je tradičně odsuzován jako něco, co nemá vědec-

1 David Freedberg - Vittorio Gallese, Motion, emotion and empathy in esthetic experience, Trends in Cognitive Sciences XI, 2007, č. 5, s. 197-203.

2 Ladislav Kesner, Dějiny umění a teorie mysli, Umění LVI, 2008, č. 1, s. 16-28. 
kou povahu, o niž dějiny umění dlouhodobě usilují. Přitom ovšem historik umění bud' musí mít aktuální poznatky o nejnovějších výzkumech v neurovědě, nebo musí těsně spolupracovat se specialisty v dané oblasti. Momentální situace je docela schizofrenická: uměnovědci se snaží ve svém uvažování využít „vědeckou“ terminologii, kterou ovšem neovládají; neurovědci na druhé straně píšou „dějiny uměni“, ke kterým také nemají kompetenci; zároveň vedle toho vznikají „nové vědy“ jako kognitivní věda, neuroestetika apod., tedy interdisciplíny snažící se vymezit jak vůči čistým dějinám umění, tak i čisté neurovědě. Ilustrací paradoxnosti této situace je fakt, že neurovědci, kteří píšou dějiny umění nově, sestavují seznamy „principů uměni“ založené na poznatcích o fungování lidského mozku, které nevědomky reflektují principy popsané již v 19. století historiky umění Wolfflinem nebo Rieglem. ${ }^{3}$

Historik umění, předmětem jehož zájmů je převážně staré umění, se při čtení moderních metodologických spisů nedokáže vyhnout pokusům aplikovat tyto modely na svoji výzkumnou oblast. Občas podobné zkoušky přivádějí uměnovědce k poměrně zajímavým závěrům. Např́íklad popisy neurovědeckých objevů v oblasti vnímání, zrcadlových neuronů a empatie mohou být porovnány s konstrukcemi, které popisují italští renesanční teoretici umění.

\section{Zrcadlové neurony a obraz}

Otázka, jak člověk vlastně vnímá obrazy, není nová: v různé míře a různé podobě se objevovala od nejstarších dob a nově se stala předmětem bádání i nedávno vzniklých neuro-dějin umění. ${ }^{4}$ Zatímco dějiny umění přistupovaly k této otázce $z$ teoretické strany, paralelně se vyvíjecí neurověda objevila fyzické podněty některých pojetí, známých již dříve ve filozofii a estetice, a to cestou vědeckých experimentů.

Ve frontálním laloku mozkové kůry existují buňky, které se aktivizují, když člověk (nebo respektive opice, na kterých byly původně tyto procesy zkoumány) provádí nějakou činnost. Například určitá buňka se aktivizuje při uchopení předmětu, jiná při jídle, třetí když jedinec něco posouvá. Veškeré neurony jsou součástí malé neuronové sítě, která má svůj určitý úkol. Tyto neurony byly známy již dávno. Během zkoumání motorických neuronů ale skupina italských vědců objevila něco velice zajímavého. ${ }^{5}$ Některé neurony se aktivovaly nejenom tehdy, když opice vykonávala nějakou činnost, ale i když jenom viděla, jak někdo vykonává něco podobného. Tyto neurony v podstatě nesou schopnost pochopit jiného. Takové neurony mají funkci čtení mysli jiné opice, jejích záměrů. U člověka jsou tyto neurony mnohem složitější a jsou schopny rozpoznat komplikovanější záměry. Tyto tzv. zrcadlové neurony umožňují imitaci cizích dějů a cizích pocitů. Postupně

3 Vilayanur Subramanian Ramachandran, The Emerging Mind, London 2003. - Idem, The Tell-Tale Brain: A Neuroscientist's Quest for What Makes Us Human, New York 2010. - Heinrich Wölfflin, Osnovnyje ponjatija istorii iskusstva. Problema evolucii stilja, Moskva 2009. - Podle Idem, Kunstgeschichtliche Grundbegriffe: Das Problem der Stilentwickelung in der neueren Kunst, München 1915.

John Onians, Neuroarthistory: From Aristotle and Pliny to Baxandall and Zeki, New Haven 2007.

5 Vittorio Gallese - Giacomo Rizzolatti - Leonardo Fogassi, Zerkalnaja čast mozga, V mire nauki III, 2007, s. 23-39. 
byly uskutečněny ještě zajímavější objevy v oblasti zrcadlových neuronů. Bylo např́klad zjištěno, že smyslové neurony bolesti reagují se stejnou silou při pozorování bolesti jiného. ${ }^{6}$

Paralelně ovšem existují mechanismy, které tento proces imitace potlačují. Porušení tohoto procesu potlačení vyvolává nemoci, jako je echopraxie, chorobné opakování toho, co dělá někdo druhý. $V$ podstatě jediná věc, která nás odděluje od jiného, je naše kủže a samozřejmě tyto potlačující mechanismy, pokud nedošlo $\mathrm{k}$ jejich narušení. ${ }^{7}$

Není divu, že objev a definice zrcadlových neuronů vzbudily novou vlnu zájmu v nejrůznějších disciplínách. Mimo jiné tyto objevy v podstatě potvrdily teorie empatie, které již byly vysloveny Robertem Vischerem nebo Theodorem Lippsem, ${ }^{8} \mathrm{i}$ když proces, jenž se obecně nazývá empatie, dodnes vyvolává spoustu otázek.

Zkoumání zrcadlových neuronů ale také ukázalo, že „zrcadlová“ reakce vzniká také při komunikaci s uměleckým dílem. Mozek diváka před obrazem se např́klad snaží skutečně napodobit emoci, kterou člověk vidí v uměleckém díle. Spolupráce Davida Freedberga a Vittoria Gallese naznačila některé možnosti, které z těchto objevů vyplývají. ${ }^{9}$

Téma emotivního soucitu s obrazem je neustále prítomné v renesančních traktátech. „Obraz milovaného“, „portrét blízkého“ - je toposem převzatým z mýtu o vynálezu maliřství u Plinia. ${ }^{10}$ Důležitou inspirací byl také výrok Horatia: „Usměvným tvářím jde úsměv vstříc a slzy nám kanou, pláče-li druhý..."11 - ve svém traktátu o malířství jej přejímá např́klad nejvýznamnější teoretik rané renesance Leon Battista Alberti ${ }^{12}$ a opakuje ho o století později rovněž Lodovico Dolce. ${ }^{13}$ Giovanni Paolo Lomazzo pak nejenom znovu přebírá tento požadavek empatie, ale rovněž ho ilustruje př́íběhem o člověku, který vždy zívl, když viděl určitou postavu, jež zívá na obraze, což je v podstatě opakováním jedné z nejznámějších demonstrací toho, jak pracují zrcadlové neurony. ${ }^{14}$

V dějinách umění lze rozlišovat dva paralelní diskurzy, které v určité míře odpovídají zrcadlovým procesům v neurovědách. Prvním je mimesis, opakování, přežívání stejného (podle Aristotela třetí typ nápodoby), ${ }^{15}$ skutečné opakování dějů, zrcadlo reality, otisk skutečnosti. Druhým diskursem je to, co náleží spíše do oblasti emocí - vdechnutí duše do uměleckého díla. Tento diskurz se oddělil ještě v antických traktátech a prolínal

6 Vilayanur Subramanian Ramachandran, Mozg rasskazyvaet: Chto delaet nas liudimi, Moskva 2014, s. 143. - (Podle Idem, The tell-tale brain. A neuroscientist's quest for what makes us human, New York 2011).

7 Ibidem, s. 144.

8 Viz Freedberg - Gallese (pozn. 1), „Box 2“, s. 198.

9 Viz Freedberg - Gallese (pozn. 1), s. 197-202.

10 Gaius Plinius Secundus - Václav Prach (edd.), O umění a umělcích, Praha 1941, s. 23.

11 Quintus Flaccus Horatius - Dana Svobodová - Eva Stehlíková (edd.), De arte poetica: O umèní básnickém, Praha 2002, s. 23.

12 Leon Battista Alberti, O malbě a.d. 1435: [Tři knihy]; O soše a.d. 1464 (Della pittura, della scultura), Praha 1947, s. 75, s. 77.

13 Lodovico Dolce, Dialogo della pittura, Venezia 1557, s. 226. - Rensselaer W. Lee, Ut pictura poesis: the humanistic theory of painting, The art bulletin XX, 1940, č. 4, s. 197-269, pozn. 92.

14 Giovanni Paolo Lomazzo, Trattato dellarte della pittura, scoltura et architettura, Milano 1584, sv. I, s. 25.

15 Aristoteles, Poetica, Praha 1962, s. 38. 
se od té doby celými dějinami umění. ${ }^{16}$ Neurobiolog Eric Kandel ve svém pojednání o umění 20. století rovněž vyznačuje dvě cesty: destrukce formy a destrukce emocí. ${ }^{17}$

Podle Leona Battisty Albertiho je vynálezcem malířství Narcis a ideálním obrazem je zrcadlová plocha. ${ }^{18}$ Je důležité ovšem upozornit i na to, že se nejedná o zrcadlovou plochu jako takovou, ale o zrcadlo, do kterého se lze zamilovat, přičemž natolik, že se to stává i prŕćinou záhuby. Alberti uvádí mýtus o Narcisovi asi proto, že byl pro čtenáře snadno pochopitelný. Jinak jsou však pro renesanční teorii umění „ritrarre“ a „imitarre“ - kopírování a napodobování - dvě různé věci. ${ }^{19}$ Ve svém pojednání o portrétní malbě Leonardo da Vinci uvádí, že opravdovým mistrem je jenom ten, kdo překonává zobrazení reality a zobrazuje duše. ${ }^{20}$

Touha vložit do obrazu lidskou duši je klíčová pro tradici klasického západního myšlení o umění. Tato touha byla charakteristická již pro antické myšlení a později byla vzkříšena právě v renesanční epoše. V Itálii se tento požadavek komunikace s obrazem objevuje v poezii doby Petrarcy, tzv. protorenesanci. Petrarca si stěžuje, že dokonalý portrét Laury objednaný u Simone Martiniho nemá hlas. ${ }^{21}$ Přitom je třeba podotknout, že se nejednalo o ideální podobnost obrazu, hyperrealismus, ale o něco více, o něco, co by našlo odpověd' u diváka. Ještě u Plinia, jehož čtení bylo v renesanční epoše obecně rozšířeno, se objevuje tvrzení, že vysoká míra totožnosti nemůže být základním kritériem pro hodnocení uměleckých děl. ${ }^{22}$ Dá se říct, že podle Plinia se takovým kritériem stalo oklamání lidského mozku. Obraz povzbuzuje k něčemu mimo sebe, k nějakému dějství, obraz může nastartovat proces zrcadlových neuronů.

Zajímavou paralelu lze najít nejenom ve spisech věnovaných přímo umění, ale i ve filozofickém uvažování renesančních myslitelů, např́ílad Marsilia Ficina. Některé pasáže z jeho Komentáře Platonova Symposionu se zdají být velice podobné popisům mechanismu zrcadlových neuronů. ${ }^{23}$ Dá se říct, že v tomto př́ípadě renesanční představa o vnitřních duševních pohybech nedělá rozdíl mezi duší a tělem. ${ }^{24}$

Jedním z požadavků Albertiho na správný obraz je to, aby na něm byla nějaká figura, která by povzbuzovala diváka k něčemu, která by upoutávala jeho pozornost a „komunikovala“ s ním. ${ }^{25}$ Podobný „dialog s divákem“ má svou paralelu v italské literatuře. ${ }^{26}$ Téma

16 Rudolf Arnheim - Vjačeslav Pavlovič Šestakov (edd.), Novyje očerky po psychologii iskusstva, Moskva 1994, s. 63-77.

17 Eric R. Kandel, Věk samopoznanija. Poiski bessoznatělnogo v iskusstvě i nauke s načala XX věka do našich dnej, Moskva 2016, s. 229-230, schéma na obr. 13-1 - Podle Idem, The age of insight: The quest to understand the unconscious in art, mind, and brain, from Vienna 1900 to the present, New York 2012.

18 Viz Alberti (pozn. 12), s. 51.

19 Vincenzo Danti, Il primo libro del trattato delle perfette proporzioni di tutte le cose che imitare e ritrarre si possano noc l'arte del disegno. Di Vincenzio Danti, Florenz 1567.

20 Leonardo da Vinci - A. A. Guber - V. K. Šilejko - A. M. Efros (edd.), Izbrannyje proizvedenija $v 2$ tomach (podle vydání 1935), Moskva 2010, díl 2, s. 219.

21 Lina Bolzoni - Federica Pich, Poesia e ritratto nel Rinascimento, Roma 2008, s. 22.

22 Viz Plinius (pozn. 10), s. 41.

23 Překlad autorky podle Marsilio Ficino - Nina Revjakina (edd.), Kommentarij na Pir Platona, in: Vasilij Zubov (ed.) Istorija estetiky. Pamjatniki mirovoj estetičeskoj mysli, Moskva, 1962, Kap VII.

24 Viz Kesner (pozn. 2), s. 96.

25 Viz Alberti (pozn. 12), s. 77.

26 Jodi Cranston, Dialogues with the beholder: The poetics of portraiture in the Italian Renaissance, Cambridge, 2000 , s. $80-84$. 
portrétu je neustále přítomné také v italské renesanční poezii. Portrétům byly věnovány sonety, dopisy, jejich popisy se stávaly podněty k vytvoření krásných literárních děl. ${ }^{27}$

Dopisy, které se nezřídka ocitají v rukou zobrazeného, nejenom poukazují na vzdělanost, ale slouží k vytvoření intimní, soukromé interakce mezi divákem a zobrazeným. ${ }^{28}$ Zobrazená osoba se snaží přibližit se divákovi, vstoupit s ním do dialogu, podobně jako podle rétorických antických př́ruček.

Zvláštní kapitolou je poetický topos „ritratto del cuore“, portrét v srdci. Na jednu stranu není takový portrét fyzický, ale je určitou myšlenkovou konstrukcí. Ovšem tento topos se hojně používal pro chvály dovedností malírư. Dílo se v podstatě „zrcadlí“ v srdci diváka, vyvolává reakci zrcadlových neuronů. ${ }^{29}$

V druhé polovině 16. století se působivost obrazu pak stala jedním ze základních principů barokního umění, podle nově kladených požadavků: Gabriele Paleotti o tom píše ve svém díle Discorso. ${ }^{30}$

Procesy, do kterých jsou zapojené zrcadlové neurony a které jsou popsány neurovědci, mají své analogie v různých podobách po celé dějiny. Zvlášt̉ jsou zajímavé diskurzy v dějinách umění, což bylo demonstrováno ve stručnosti na příkladu renesančního umění. Poetické metafory mohou být chápány nejenom jako rétorická hra, ale zároveň jako analogie k neurovědě. Analogii fyzických procesů, neurologických reakcí lze nalézt nejenom v traktátech o umění, ale i v religiózní literatuře, krásné literatuře, dopisech, básnictví, traktátech o hudbě.

\section{Top-down proces a pojetí disegno nebo ideje v teorii umění}

Další oblastí, ve které se najdou analogické konstrukce, je teorie sestupujících a nastupujících procesů při vnímání. Lidská percepce je vždycky obousměrným procesem. $\mathrm{Na}$ jednu stranu dostáváme informaci z vnějšku: to, co ovlivňuje naše smyslové orgány. Na druhou stranu to, co vnímáme, je definováno naší zkušeností, naším předcházejícím věděním, našimi potřebami, představami, připraveností, ochotou něco vnímat.

Hermann von Helmholtz v polovině 19. století vyslovil teorii o rozdělení dvou představ: prvotní obraz, který vzniká jenom díky nějakému vlivu z vnějšku, a představa vnitřní - naše poznatky, které pomáhají rozpoznat objekt jako takový. Tyto procesy jsou neoddělitelné a paralelní.

$\mathrm{V}$ biologii se používají termíny bottom-up a top-down procesy. První jsou procesy postupující „zdola nahoru“: informace se od smyslových orgánů dostává do centrální nervové soustavy přes podkorové struktury do mozkové kůry. Tento proces je doprovázen, dokonce předcházen procesem opačným, sestupujícím shora od mozkových center

27 Federica Pich, I poeti davanti al ritratto: Da Petrarca a Marino, Lucca 2010, s. 275. - Viz také Bolzoni - Pich (pozn. 21).

28 Viz Cranston (pozn. 26), s. 79.

29 John K. G. Shearman, Only connect: Art and the spectator in the Italian Renaissance, Princeton 1992, s. 147 , pozn. 69.

30 David Ganz, Tra paura e fascino: La funzione comunicativa delle immagini visive nel "Discorso" di Gabriele Paleotti, Heidelberg 2000, s. 57-68. 
k periferním: informace sestupuje od frontálního laloku k níže ležícím strukturám. ${ }^{31}$ Zpětné neurální obvody dokonce mohou převažovat nad zmíněným „vzestupujícím“ procesem. Dá se rríct, že sestupující proces se skládá ze dvou základních součástí: na jednu stranu jsou to naše zkušenosti a předsudky (nařízení), na druhou stranu jsou to způsoby řešení vizuálního úkolu záležející na konkrétním kontextu.

V dějinách uměníje asi nejznámějším příkladem práceErnsta Gombricha, kterýse zajímal o podobná dvojznačná zobrazení. ${ }^{32} \mathrm{~V}$ určité miřre podobný princip leží v základu ikonograficko-ikonologické analýzy Erwina Panofského. ${ }^{33}$ Ernst Kris, žák Maxe Dvořáka a Julia Schlossera a spolupracovník Gombricha v Londýně, se také přikláněl k využití psychoanalýzy v dějinách umění. ${ }^{34}$

Určitou analogii této struktury lze nalézt $\mathrm{v}$ popisech jednoho ze základních pojetí pro umění renesance a manýrismu. Disegno je zvláštní pojem, který se v dějinách umění dlouho vyvíjel. Na začátku bylo disegno pojímáno jenom jako skutečný akt kresby, ale v 16. století se disegno stává složitou filozofickou koncepcí, kterou se snažili definovat a popsat různí teoretikové manýrismu. Dá se ř́íct, že spirituální dimenze nabývá disegno počínaje spisy Vasariho. ${ }^{35}$ Přestože definování složité koncepce pravděpodobně nebylo cílem italského životopisce, lze vidět, že disegno $v$ jeho pojetí již přesahuje rámec pouze technické dovednosti. V druhém vydání Životopisů z roku 1568 Vasari popisuje kresbu (disegno) jako „názorné vyjádření a objasnění, concetta, které má své místo pưvodně v duchu, je představováno v mysli a přinášeno na světlo umèní.

Představu o tom, že umění se nerodí ani na papíru, ani na nebi, ale př́mo v hlavě umělce lze najít nejenom $\mathrm{v}$ renesančních traktátech, ale rovněž i v obecnějších textech, dopisech. ${ }^{36}$ Raffaele Borghini a Giovanni Battista Armenini pokračují v linii započaté Vasarim. Ve spisu Borghiniho Riposo (1584) o disegnu mluví jeden z protagonistů dialogu Sirigatto. ${ }^{37}$

Giovanni Battista Armenini ve svém traktátu De veri precetti della pittura pozdvihuje disegno ještě výše, v duchu stř̌edověké scholastiky..$^{38} \mathrm{~K}$ té, konkrétně spisům Tomáše Akvinského, se ve svém pojednání vrací i Federico Zuccaro, zatímco Anton Paolo Lomazzo aplikuje pro svou teorii novoplatonická uvažování Marsilia Ficina. Lomazzo se v porovnání se Zuccarem zdá praktičtějším teoretikem, snažícím se dát umělcům rady, které lze aplikovat v praxi. Zuccaro pokračuje dále ve svých spekulacích a v podstatě „osvobozuje“ vnitřní kresbu od konkrétních praktických nařízení. Stručně lze říct, že

31 Mark J. Fenske - Elissa Aminoff - Nurit Gronau - Moshe Bar, Top-down facilitation of visual object recognition: object-based and context-based contributions, Progress in Brain Research CLV, 2006, s. 3-18.

32 Ernst H. Gombrich, Umění a iluze, Praha 1985.

33 Viz Kandel (pozn. 17), s. 335.

34 Ernst Kris - Ernst H. Gombrich, The principles of caricature, Cambridge 1938.

35 Giorgio Vasari - A. I. Gabričevskij - A. I. Venediktov (edd.), Žizněopisanija naibolee znamenitych živopistcev, vajatelej i zodčich, polnoje izdanije v odnom tomě, Moskva 2008, s. 40-41.

36 David Efimovič Arkin - Boris Nikolajevič Ternovetz (edd.), Mastera iskusstva ob iskusstvě, v 4 tomach, Moskva - Leningrad 1937, sv. I, s. 178.

37 Překlad autorky podle Gianni Carlo Sciolla, Primato del disegno: un dibattico accademico nel Rinascimento, in: Annamaria Petriolo Tofani - Simonetta Prosperi Valenti Rodino - Gianni Carlo Sciolla (edd.), Il disegno: Forme, tecniche, significati (I), Torino 1991, s. 25.

38 Ibidem, s. 26. - Erwin Panofsky, Idea: $k$ istorii ponjatija $v$ teorijach iskusstva ot antičnosti do klassicisma, Sankt-Peterburg 2002. (České vydání: Idem, Idea: Př́spěvek k historii pojmu starši teorie umění, Praha 2014, s. 177.) 
zatímco u Vasariho „dirigovala“ skutečná kresba, u Zuccara „první housle“ hraje idea. Zatímco Vasari „dodal“ pojetí kresby spirituální dimenzi, Zuccaro v podstatě nahradil slovo „idea“ slovem kresba, které je podle jeho názoru vhodnější pro umělecké prostředí.

Podle schématu, které nabízíZuccaro, obsahuje pojetí disegna dvě nedílné součásti: vnitřní a vnější disegno. Každému věnuje Zuccaro zvláštní knihu, kde pojednává o jejich vlastnostech. Na konci druhé knihy podává Zuccaro jakýsi přehled definic disegna, které řadí od skutečného aktu do nejvyšší božské hodnoty. Nejzajímavější jsou pro nás čtvrtá a osmá:

4. Vnitřní vzor všech uměleckých provedení [...]

8. Vnitřní prvotní hybná síla, počátek a konec naši činnosti ${ }^{39}$

Přes veškeré rozdíly je společným rysem traktátů Lomazza a Zuccara to, že skutečné „nejvyššíi disegno/idea se rodí ještě před skutečným aktem, zjevuje se malíři přes nějakou božskou sílu. Tento proces lze považovat za nezáměrnou alegorii procesu „top-down“, zpětných neurálních obvodů, které usnadňují rychlou interpretaci vizuálních obrazů člověkem.

Podle renesančních teoretiků se dá disegnu naučit během nepřerušovaného nácviku studia reality, skládání „kouskư“ v nějaký „celek“ ve své hlavě, který se pak ztělesní ve skutečném aktu disegna. Neurověda rovněž upozorňuje na důležitou roli kontextu a asociací, na „spoření“ informací v mozkové kưře, na základě čehož pak vznikají ty samé reakce sestupující shora dolů. ${ }^{40}$

Zájem o proces zrození umění před jeho skutečnou realizací vyvrcholil právě v manýristických traktátech italských teoretiků. V různých podobách se objevoval i v následujících stoletích, ovšem až v poslední době získala tato teorie konečně své potvrzení v oblasti neurovědy. Výzkumy v oblasti neurovědy tím pádem bezděky potvrzují „nevědecká“ uvažování myslitelů 16 . století.

\section{Závěr}

Závěrem tohoto krátkého příspěvku nabízím soubor otázek, které jsou zároveň výzvou pro následující bádání:

1. Jaké jsou možnosti neurovědy a různých jejích odvětví v dějinách a teorii umění? Nakolik by mohla být př́nosná jejich vzájemná spolupráce?

3. Možnosti aprobace tendencí ze současné metodologie na starém umění: nakolik jsou př́nosné podobné pokusy?

4. Jak staré umění pracovalo s mechanismy, o kterých se uvažuje převážně v souvislosti s moderním uměním?

Díky objevi̊m v neurovědě mohou být otevřeny nové diskurzy ve starém umění, některé $\mathrm{z}$ nich byly naznačeny v předkládaném prríspěvku:

39 Překlad autorky podle Federico Zuccaro, L'idea de' Pittori, Scultori et Architetti (p. 2), Torino 1607. Viz: http://gallica.bnf.fr/ark:/12148/bpt6k1119027, vyhledáno 24. 8. 2017, sv. II, kap. 15, s. 192. - Také viz Panofsky (pozn. 38), s. 175 a Sciolla (pozn. 37), s. 26.

$40 \quad$ Viz Kandel (pozn. 17), kap. 18. 
- problematika středověkého obrazu a mysticismu, téma stigmat a popisy mystických zážitků při pozorování uměleckých děl z pohledu neurovědy;

- renesanční teorie maliřství, literární a poetická topoi, která vyžadují komunikaci s divákem z pohledu teorie empatie;

- „božské“ disegno jako analogie předkognitivních procesů;

- požadavky tridentského koncilu kladené na umění: co vyžadovala církev od obrazu z pohledu neurovědy.

Dá se říct, že výsledky nejnovějších bádání v oblasti neurologie se mohou stát katalyzátorem významných změn v uměnovědě. Dějiny umění se mohou stát jakýmsi středem, křížením různých disciplín. Otázkou zůstává však to, jestli se dějiny umění podobné změny odváží, nebo ne.

\section{LITERATURA}

Leon Battista Alberti, O malbě a.d. 1435: [Tři knihy]; O soše a.d. 1464 (Della pittura, della scultura), Praha 1947.

Aristoteles, Poetica, Praha 1962.

David Efimovič Arkin - Boris Nikolajevič Ternovetz (edd.), Mastera iskusstva ob iskusstvě, v 4 tomach, Moskva - Leningrad 1937, sv. I.

Rudolf Arnheim - Vjačeslav Pavlovič Šestakov (edd.), Novyje očerky po psychologii iskusstva, Moskva 1994.

Lina Bolzoni - Federica Pich, Poesia e ritratto nel Rinascimento, Roma 2008.

Jodi Cranston, Dialogues with the beholder: The poetics of portraiture in the Italian Renaissance, Cambridge 2000.

Vincenzo Danti, Il primo libro del trattato delle perfette proporzioni di tutte le cose che imitare e ritrarre si possano noc l'arte del disegno. Di Vincenzio Danti, Florenz 1567.

Lodovico Dolce, Dialogo della pittura, Venezia 1557, s. 226. - Rensselaer W. Lee, Ut pictura poesis: the humanistic theory of painting, The art bulletin XX, 1940, č. 4, s. 197-269, pozn. 92.

Mark J. Fenske - Elissa Aminoff - Nurit Gronau - Moshe Bar, Top-down facilitation of visual object recognition: object-based and context-based contributions, Progress in Brain Research CLV, 2006, s. 3-18.

Marsilio Ficino - Nina Revjakina (edd.), Kommentarij na Pir Platona, in: Vasilij Zubov (ed.) Istorija estetiky. Pamjatniki mirovoj estetičeskoj mysli, Moskva, 1962, Kap VII.

David Freedberg - Vittorio Gallese, Motion, emotion and empathy in esthetic experience, Trends in Cognitive Sciences XI, 2007, č. 5.

Vittorio Gallese - Giacomo Rizzolatti - Leonardo Fogassi, Zerkalnaja čast̉ mozga, V mire nauki III, 2007.

David Ganz, Tra paura e fascino: La funzione comunicativa delle immagini visive nel „Discorso" di Gabriele Paleotti, Heidelberg 2000.

Ernst H. Gombrich, Umění a iluze, Praha 1985.

Quintus Flaccus Horatius - Dana Svobodová - Eva Stehlíková (edd.), De arte poetica: O umění básnickém, Praha 2002.

Eric R. Kandel, Věk samopoznanija. Poiski bessoznatělnogo v iskusstvě i nauke s načala XX věka do našich dnej, Moskva 2016.

Eric R. Kandel, The age of insight: The quest to understand the unconscious in art, mind, and brain, from Vienna 1900 to the present, New York 2012.

Ladislav Kesner, Dějiny umění a teorie mysli, Umění LVI, 2008, č. 1.

Ernst Kris - Ernst H. Gombrich, The principles of caricature, Cambridge 1938.

Gaius Plinius Secundus - Václav Prach (edd.), O umění a umělcích, Praha 1941.

Giovanni Paolo Lomazzo, Trattato dellarte della pittura, scoltura et architettura, Milano 1584, sv. I.

John Onians, Neuroarthistory: From Aristotle and Pliny to Baxandall and Zeki, New Haven 2007.

Erwin Panofsky, Idea: $k$ istorii ponjatija $v$ teorijach iskusstva ot antičnosti do klassicisma, Sankt-Peterburg 2002. (České vydání: Idem, Idea: Př́spěvek k historii pojmu starší teorie umění, Praha 2014.) 
Federica Pich, I poeti davanti al ritratto: Da Petrarca a Marino, Lucca 2010.

Gianni Carlo Sciolla, Primato del disegno: un dibattico accademico nel Rinascimento, in: Annamaria Petriolo Tofani - Simonetta Prosperi Valenti Rodino - Gianni Carlo Sciolla (edd.), Il disegno: Forme, tecniche, significati (I), Torino 1991.

John K. G. Shearman, Only connect: Art and the spectator in the Italian Renaissance, Princeton 1992.

Vilayanur Subramanian Ramachandran, The Emerging Mind, London 2003.

Vilayanur Subramanian Ramachandran, The Tell-Tale Brain: A Neuroscientist's Quest for What Makes Us Human, New York 2010.

Vilayanur Subramanian Ramachandran, Mozg rasskazyvaet: Chto delaet nas liud'mi, Moskva 2014.

Giorgio Vasari - A. I. Gabričevskij - A. I. Venediktov (edd.), Žizněopisanija naibolee znamenitych živopistcev, vajatelej i zodčich, polnoje izdanije v odnom tomě, Moskva 2008.

Leonardo da Vinci - A. A. Guber - V. K. Šilejko - A. M. Efros (edd.), Izbrannyje proizvedenija v 2 tomach (podle vydání 1935), Moskva 2010, díl 2.

Heinrich Wölfflin, Osnovnyje ponjatija istorii iskusstva. Problema evolucii stilja, Moskva 2009.

Federico Zuccaro, L'idea de' Pittori, Scultori et Architetti (p. 2), Torino 1607. Viz: http://gallica.bnf.fr /ark:/12148/bpt6k1119027, vyhledáno 24. 8. 2017, sv. II, kap. 15. 